Review Articles

\title{
Classification, nosology and diagnostics of Ehlers-Danlos syndrome
}

\author{
Ben C.J. Hamel* \\ Department of Human Genetics, Radboud university medical center, Nijmegen, The Netherlands
}

\begin{abstract}
Article Info
History

Received : 23 March 2019

Accepted : 10 Oct 2019

Available : 31 Dec 2019

Abstract

Ehlers-Danlos syndrome (EDS) comprises a group of heritable connective tissue disorders which has as cardinal features varying degrees of skin hyperextensibility, joint hypermobility, easy bruising and skin fragility. The 2017 New York nosology distinguishes 13 types of EDS, which all, except hypermobile EDS, have a known molecular basis. Hypermobile EDS is recognized as a common and often disabling disorder, incorporating benign joint hypermobility syndrome. EDS needs to be differentiated from other connective tissue disorders, in particular Marfan syndrome, Loeys-Dietz syndrome and cutis laxa. The frequent types of EDS can be diagnosed after careful history taking and clinical examination, but for definite diagnosis, molecular confirmation is needed in all types. Management for EDS patients preferably is provided by multidisciplinary teams in expertise centres. After diagnosing EDS, genetic counselling is an essential part of the management of patients and their family.
\end{abstract}

Keywords : Ehlers-Danlos syndrome; classification; diagnosis

Permalink/ DOI: https://doi.org/10.14710/jbtr.v5i2.4531

\section{INTRODUCTION}

EDS comprises a clinically and genetically heterogeneous group of heritable connective tissue disorders (HCTD), mainly characterized by a variable degree of generalized joint hypermobility, skin hyperextensibility, easy bruising and skin fragility. In his classical monograph on EDS, published in 1970, Beighton described 5 EDS types: I = gravis (severe), II $=$ mitis (mild), III = hypermobility, IV = ecchymotic, and $\mathrm{V}=\mathrm{X}$-linked. ${ }^{1}$ The Berlin classification listed 11 EDS types. ${ }^{2}$ Revision became necessary because of new biochemical, molecular and clinical data, leading to the Villefranche nosology of 1997, in which 6 EDS types were recognized. ${ }^{3}$ New clinical and molecular data required another revision, which was initiated during the Ehlers-Danlos Society International Symposium in New York, May 2016, the results of which have been published in the March 2017 issue of the American Journal of Medical Genetics Part C, Seminars in Medical Genetics.

\footnotetext{
* Corresponding author:

E-mail: b.hame11503@gmail.com;

ben.hamel@radboudumc.nl (Ben C.J. Hamel)
}

The most striking changes were:

- incorporating EDS types which were published since the Villefranche nosology, leading to a total number of 13 types. $^{4}$

- deciding - not unexpectedly though - that EDS hypermobility type and benign joint hypermobility syndrome (BJHS; also called joint hypermobility syndrome or hypermobility syndrome) are in fact part of one and the same clinical spectrum ranging from apparently symptomatic generalized joint hypermobility to the more disabled individuals fitting the new diagnostic criteria. These new criteria are more strict than the Villefranche criteria and the Brighton criteria for BJHS in order to define a homogeneous phenotype for management and scientific purposes. Its name is hypermobile EDS.

It always has been, and still is, a challenge to classify individual patients in one of the existing EDS types. Often this is not possible and therefore there is still room for new types. This is, among other things, due to:

- the clinical overlap between many of these EDS types 
- $\quad$ absence of a pathogenic variant in any of the known EDS associated genes in an important proportion of EDS patients.

- the presence of associated features which do not fit into one of the existing types.

- the absence of a laboratory test for hypermobile EDS.

EDS is not a rare disorder; the prevalence is estimated to be about 1:5000. The hypermobile type - by far the most common - and the classical type comprise more than $90 \%$ of all cases. ${ }^{5}$

\section{CLASSIFICATION AND NOSOLOGY}

The New York classification is based on clinical, biochemical and molecular data. ${ }^{4}$ Table 1 shows the New York nosology alongside the previous nosologies with inheritance patterns, genetic bases and proteins, while in table 2, EDS types are grouped according to underlying genetic and pathogenetic mechanisms; OMIM numbers are added.
Skin hyperextensibility should be tested at specific sites, e.g. the volar side of the non-dominant forearm or the dorsum of the hand by pulling up the skin until resistance is felt. In contrast to cutis laxa, a group of clinically and genetically heterogeneous disorders characterised by redundant, sagging and inelastic skin, with or without joint hypermobility, in EDS the skin snaps back after release. ${ }^{6}$ The upper limit of normal for the forearm and dorsum of the hand is about $1 \frac{1 / 2}{\mathrm{~cm}} .^{7} \mathrm{In}$ young children, it is difficult to assess hyperextensibility due to the abundance of subcutaneous fat. Skin hyperextensibility can also be assessed at the dorsal aspect of the elbow in $90^{\circ}$ flexion, where the upper limit of normal is $3 \mathrm{~cm}$.

Joint hypermobility is scored using the Beighton mobility scale (table 3). In the New York nosology, a score of 5/9 or more defines generalized hypermobility in both sexes, though it is known that joint mobility depends, apart from age, family and ethnic background, also on gender. Since laxity decreases with age, patients with a Beighton score $<5 / 9$ may be considered positive

Table 1 Classification of Ehlers-Danlos syndrome (adapted from ${ }^{4}$ )

\begin{tabular}{|c|c|c|c|c|c|}
\hline $\begin{array}{l}\text { Berlin } \\
\text { classification } \\
(\mathbf{1 9 8 8 )} \\
11 \text { types }\end{array}$ & $\begin{array}{l}\text { Villefranche } \\
\text { classification } \\
(1997) \\
6 \text { types }\end{array}$ & $\begin{array}{l}\text { International } \\
\text { classification } \\
(2017) \\
13 \text { types }\end{array}$ & IP & Genetic basis & Protein \\
\hline \multirow[t]{3}{*}{$\begin{array}{l}\text { Type I (gravis) } \\
\text { and type II } \\
\text { (mitis) }\end{array}$} & Classical type & $\begin{array}{l}\text { Classical EDS } \\
\text { cEDS }\end{array}$ & $\mathrm{AD}$ & $\begin{array}{l}\text { Major: COL5A1, COL5A1 } \\
\text { Rare*: COL1A1 } \\
\text { c.934C>T, p.(Arg312) }\end{array}$ & $\begin{array}{l}\text { Type V collagen } \\
\text { Type I collagen }\end{array}$ \\
\hline & & $\begin{array}{l}\text { Classical-like EDS } \\
\text { clEDS }\end{array}$ & AR & $T N X B$ & Tenascin XB \\
\hline & & $\begin{array}{l}\text { Cardiac-valvular EDS } \\
\text { cvEDS }\end{array}$ & AR & $\begin{array}{l}\text { COL1A2 (biallelic mutations that } \\
\text { lead to COL1A2 NMD and } \\
\text { absence of pro a2(I) collagen } \\
\text { chains) }\end{array}$ & Type I collagen \\
\hline $\begin{array}{l}\text { Type } \\
\text { IVA,B,C,D }\end{array}$ & Vascular type & $\begin{array}{l}\text { Vascular EDS } \\
\text { vEDS }\end{array}$ & $\mathrm{AD}$ & $\begin{array}{l}\text { Major: } C O L 3 A 1 \\
\text { Rare: } C O L 1 A 1 \\
\text { c.934C>T, p.(Arg312Cys) } \\
\text { c. } 1720 \mathrm{C}>\mathrm{T}, \text { p.(Arg574Cys) } \\
\text { c.3227C }>\mathrm{T}, \text { p.(Arg1093Cys) }\end{array}$ & $\begin{array}{l}\text { Type III collagen } \\
\text { Type I collagen }\end{array}$ \\
\hline Type III & $\begin{array}{l}\text { Hypermobility } \\
\text { type }\end{array}$ & $\begin{array}{l}\text { Hypermobile EDS } \\
\text { hEDS }\end{array}$ & $\mathrm{AD}$ & Unknown & Unknown \\
\hline $\begin{array}{l}\text { Type VIIA and } \\
\text { B }\end{array}$ & $\begin{array}{l}\text { Arthrochalasia } \\
\text { type }\end{array}$ & $\begin{array}{l}\text { Arthrochalasia EDS } \\
\text { aEDS }\end{array}$ & $\mathrm{AD}$ & COL1A1, COL1A2 & Type I collagen \\
\hline Type VIIC & $\begin{array}{l}\text { Dermatosparaxis } \\
\text { type }\end{array}$ & $\begin{array}{l}\text { Dermatosparaxis EDS } \\
\text { cEDS }\end{array}$ & AR & ADAMTS2 & ADAMTS-2 \\
\hline Type VIA & $\begin{array}{l}\text { Kyphoscoliotic } \\
\text { type }\end{array}$ & $\begin{array}{l}\text { Kyphoscoliotic EDS } \\
\text { kEDS }\end{array}$ & AR & $\begin{array}{l}\text { PLOD1 } \\
\text { FKBP14 }\end{array}$ & $\begin{array}{l}\text { LH1 } \\
\text { FKBP22 }\end{array}$ \\
\hline \multirow[t]{2}{*}{ Type VIB } & & $\begin{array}{l}\text { Brittle cornea } \\
\text { syndrome } \\
\text { BCS }\end{array}$ & AR & $\begin{array}{l}\text { ZNF469 } \\
\text { PRDM5 }\end{array}$ & $\begin{array}{l}\text { ZNF469 } \\
\text { PRDM5 }\end{array}$ \\
\hline & & $\begin{array}{l}\text { Spondylodysplastic } \\
\text { EDS } \\
\text { spEDS }\end{array}$ & AR & $\begin{array}{l}\text { B4GALT7 } \\
\text { B3GALT6 } \\
\text { SLC } 39 A 13 \\
\end{array}$ & $\begin{array}{l}\text { b4GalT7 } \\
\text { b3GalT6 } \\
\text { ZIP13 }\end{array}$ \\
\hline \multirow[t]{2}{*}{ Type VIB } & & $\begin{array}{l}\text { Musculocontractural } \\
\text { EDS } \\
\text { mcEDS }\end{array}$ & AR & $\begin{array}{l}\text { CHST14 } \\
\text { DSE }\end{array}$ & $\begin{array}{l}\text { D4ST1 } \\
\text { DSE }\end{array}$ \\
\hline & & $\begin{array}{l}\text { Myopathic EDS } \\
\text { mEDS }\end{array}$ & $\begin{array}{l}\mathrm{AD} / \\
\mathrm{AR}\end{array}$ & COL12A1 & Type XII collagen \\
\hline EDS VIII & & $\begin{array}{l}\text { Periodontal EDS } \\
\text { pEDS }\end{array}$ & $\mathrm{AD}$ & $\begin{array}{l}\text { C1R } \\
C 1 S\end{array}$ & $\begin{array}{l}\text { C1r } \\
\text { C1s }\end{array}$ \\
\hline
\end{tabular}

IP: inheritance pattern

NMD: nonsense mediated decay

* EDS classical type with (propensity to) arterial rupture. ${ }^{12}$

In clinical practice, the clinical manifestations guide the choice for further investigations. The major clinical manifestations of EDS need some clarification, however. based on their historical observations (five-point questionnaire $=5 \mathrm{PQ}$; see footnote with table 4). For the diagnosis of hypermobile EDS different age and sex specific cut-off points were proposed (see table 4). In 
Table 2 EDS grouping according to underlying genetic and pathogenetic mechanisms (adapted from ${ }^{4}$ )

\begin{tabular}{|c|c|c|c|c|}
\hline Berlin or earlier name & Villefranche name & New York name & OMIM & Gene \\
\hline \multicolumn{5}{|c|}{ GROUP A: Disorders of collagen primary structure and collagen processing } \\
\hline $\begin{array}{l}\text { EDS I } \\
\text { EDS II }\end{array}$ & Classical type & Classical EDS (cEDS) & 130000 & $\begin{array}{l}\text { COL5A1 } \\
\text { COL5A2 }\end{array}$ \\
\hline EDS IV & Vascular type & Vascular EDS (vEDS) & 130010 & COL3A1 \\
\hline $\begin{array}{l}\text { EDS VIIA } \\
\text { EDS VIIB }\end{array}$ & Arthrochalasia type & Arthrochalasia EDS (aEDS) & $\begin{array}{l}130060 \\
130080\end{array}$ & Type I collagen \\
\hline EDS VIIC & Dermatosparaxis type & Dermatosparaxis EDS (dEDS) & 225410 & ADAMTS2 \\
\hline Cardiac-valvular EDS & ----- & Cardiac-valvular EDS (cvEDS) & 225320 & Type 1 collagen \\
\hline \multicolumn{5}{|c|}{ GROUP B: Disorders of collagen folding and collagen cross-linking } \\
\hline $\begin{array}{l}\text { Ocular-scoliotic EDS } \\
\text { EDS VI/VIA }\end{array}$ & Kyphoscoliotic type & $\begin{array}{l}\text { Kyphoscoliotic EDS (kEDS- } \\
\text { PLOD1) }\end{array}$ & 225400 & PLOD1 \\
\hline---- & ---- & $\begin{array}{l}\text { Kyphoscoliotic EDS (kEDS- } \\
F K B P 14 \text { ) }\end{array}$ & 614557 & FKBP14 \\
\hline \multicolumn{5}{|c|}{$\begin{array}{l}\text { GROUP C: Disorders of structure and function of myomatrix, the interface between muscle and ExtraCellular } \\
\text { Matrix }\end{array}$} \\
\hline---- & ---- & Classical-like EDS (clEDS) & 606408 & $T N X B$ \\
\hline---- & ---- & Myopathic EDS (mEDS) & 616471 & COL12A1 \\
\hline \multicolumn{5}{|c|}{ GROUP D: Disorders of glycosaminoglycan biosynthesis } \\
\hline EDS progeroid type 1 & ---- & $\begin{array}{l}\text { Spondylodysplastic EDS } \\
\text { (spEDS- } B 4 G A L T 7 \text { ) }\end{array}$ & 130070 & B4GALT7 \\
\hline EDS progeroid type 2 & $\begin{array}{c}--- \\
\end{array}$ & $\begin{array}{l}\text { Spondylodysplastic EDS } \\
\text { (spEDS-B3GALT6) }\end{array}$ & 615349 & B3GALT6 \\
\hline $\begin{array}{l}\text { Adducted thumb- } \\
\text { clubfoot syndrome } \\
\text { Musculocontractural } \\
\text { type } \\
\text { EDS Kosho type } \\
\text { D4ST1 deficient EDS }\end{array}$ & ---- & $\begin{array}{l}\text { Musculocontractural EDS } \\
\text { (mcEDS-CHST14) }\end{array}$ & 601776 & CHST14 \\
\hline---- & $\begin{array}{c}--- \\
\end{array}$ & $\begin{array}{l}\text { Musculocontractural EDS } \\
\text { (mcEDS-DSE) }\end{array}$ & 615539 & $D S E$ \\
\hline \multicolumn{5}{|c|}{ GROUP E: Disorders of complement pathway } \\
\hline EDS VIII & Periodontitis type & Periodontal EDS (pEDS) & 130080 & $C 1 R, C 1 S$ \\
\hline \multicolumn{5}{|c|}{ GROUP F: Disorders of intracellular processes (provisional) } \\
\hline $\begin{array}{l}\text { Spondylocheirodysplast } \\
\text { ic EDS }\end{array}$ & $\begin{array}{ll}--- \\
\end{array}$ & $\begin{array}{l}\text { Spondylodysplastic EDS } \\
\text { (spEDS-SLC39A13) }\end{array}$ & 612350 & SLC39A13 \\
\hline $\begin{array}{l}\text { Brittle cornea } \\
\text { syndrome }\end{array}$ & ---- & Brittle cornea syndrome (BCS) & $\begin{array}{l}229200 \\
614170 \\
\end{array}$ & $\begin{array}{l}\text { ZNF469 } \\
\text { PRDM5 } \\
\end{array}$ \\
\hline \multicolumn{5}{|l|}{ Unresolved form of EDS } \\
\hline EDS III & Hypermobility type & Hypermobile EDS (hEDS) & 130020 & $? ?$ \\
\hline
\end{tabular}

Table 3 Beighton mobility scoring scale*

\begin{tabular}{|l|c|c|c|}
\hline Joint & Negative & Unilateral & Bilateral \\
\hline $\begin{array}{l}\text { Passive dorsiflexion of the } 5^{\text {th }} \\
\text { finger }>90^{\circ}\end{array}$ & 0 & 1 & 2 \\
\hline $\begin{array}{l}\text { Passive flexion of thumbs to the } \\
\text { forearm }\end{array}$ & 0 & 1 & 2 \\
\hline $\begin{array}{l}\text { Hyperextension of the elbows }> \\
10^{\circ}\end{array}$ & 0 & 1 & 2 \\
\hline $\begin{array}{l}\text { Hyperextension of the knees }> \\
10^{\circ}\end{array}$ & 0 & & \\
\hline $\begin{array}{l}\text { Forward flexion of the trunk with } \\
\text { knees fully extended and palms } \\
\text { resting on the floor }\end{array}$ & 0 & & \\
\hline Maximum total score & & & \\
\hline * a score of 5/9 or more defines generalized joint hypermobility for both sexes (for hypermobile EDS age and sex related \\
cut-off points are used; see table 4)
\end{tabular}

children under the age of about 5 years, the Beighton scale is less useful.

Generalised hypermobility is not rare: $5-10 \%$ of mainly female - secondary school age Caucasian children is hypermobile and this percentage is higher in Asian populations. ${ }^{7,8}$

Easy bruising is seen as spontaneous ecchymoses, frequently recurring in the same bodily regions, of which long-term signs are often visible as brownish discoloration (haemosiderin), in particular on knees and shins. If it is the predominant presenting sign, child abuse and bleeding disorders need to be considered first.

Tissue fragility is manifested in the skin as easy bruising and impaired wound healing with dystrophic scars, which are usually found over pressure points like forehead, chin, elbow, knee and shin and which may have a wide 
and papyraceous appearance. Internal organs like arteries, lungs, intestines, liver, spleen and uterus may also show fragility, predominantly in the vascular type.

Some features are regularly observed, but are not criteria of generalised hypermobility syndromes. One example is the ineffectiveness of local anaesthetics in hypermobile EDS. ${ }^{9}$

Table 4 shows the major and minor diagnostic criteria, minimal criteria for diagnosis and how to verify the diagnosis.

A major diagnostic criterion has high diagnostic specificity, which means that it is present in the vast majority of the affected individuals and/or it is characteristic for the disorder and allows differentiation from other EDS types and/or other HCTD. A minor criterion is a sign of lesser diagnostic specificity, but its presence supports the diagnosis. However, in the absence of major criteria, minor criteria are not sufficient for a given diagnosis. Because of the vast genetic heterogeneity and phenotypic variability of the EDS types and the clinical overlap between many of these, the definite diagnosis relies for all types, except the hypermobile type, on molecular confirmation.

In older publications, features like facial dysmorphisms and mental retardation/intellectual disability were attributed to EDS, whereas nowadays these features are not any longer considered characteristics of EDS, except for facial dysmorphisms in vascular, dermatosparaxis, spondylodysplastic and musculocontractural EDS and intellectual disability in spondylodysplastic EDS (see table 4). Explanation for this could be that other syndromes associated with these features were erroneously diagnosed as EDS because of overlapping features with EDS. Another explanation is that these other features are not rare and consequently are found associated with EDS in a low percentage of cases.

The classical EDS has all the skin and joint characteristics of EDS, though in variable range of severity. Minimal diagnostic criteria are the presence of skin hyperextensibility and atrophic scars, plus either generalized joint hypermobility and/or 3 minor criteria (for details see table 4). ${ }^{10} \mathrm{~A}$ recent paper reviewed 62 molecularly confirmed cases from Italy. ${ }^{11}$ It is inherited in an autosomal dominant fashion. However, sporadic cases (i.e. without an affected parent) do occur due to a spontaneous mutation. Genetically, it is heterogeneous since in over $90 \%$ of patients, who fulfil all major criteria, a defect can be found in (products of) one of the two genes that are up to now known to be involved, COL5A1 and COL5A2. An EDS type resembling the classical type but clinically characterized by a propensity to arterial rupture and molecularly by a specific mutation in COL1A1 (c.934C>T; p.Arg312Cys) is regarded as a variant type of classical EDS. ${ }^{12,13}$ The major differential diagnosis of the classical type, at least in a sporadic case, is the classical-like EDS. Also, in mild cases of the classical type (partial expression), differentiation from the hypermobile type might be difficult, if not impossible.

Classical-like EDS resembles the classical type, however with normal wound healing and scar formation. ${ }^{13,14}$ Minimal diagnostic criteria are the presence of all 3 major criteria, i.e. skin hyperextensibility, generalized joint hypermobility and easy bruisability and a family history compatible with autosomal recessive inheritance. It is characterised by generalized hypermobility, with a remarkable laxity of finger joints. In contrast with the classical type, its inheritance is autosomal recessive, so most cases are sporadic and some occur in sibships. It is due to tenascin$\mathrm{X}$ deficiency. In serum, tenascin- $\mathrm{X}$ is completely absent and mutation analysis of the $T N X-B$ gene reveals biallelic mutations.

The cardiac valvular EDS is rare. ${ }^{13,15}$ Apart from typical EDS features, it is associated with severe aortic and/or mitral valve insufficiency, necessitating valve replacement at relatively young age. Minimal diagnostic criteria are the presence of severe progressive cardiacvalvular problems, family history compatible with AR inheritance plus either one other major criterion and/or at least 2 minor (for details see table 4). The inheritance is autosomal recessive. It is due to homozygous or compound heterozygous COL1A2 null mutations.

The vascular EDS is the most severe form of EDS. ${ }^{16}$ Minimal diagnostic criteria are the presence of a family history of vascular EDS, arterial rupture/dissection $<40$ years, unexplained sigmoid colon rupture or spontaneous pneumothorax in the presence of other features consistent with vascular EDS. These and a combination of minor criteria warrant verifying diagnostic tests, i.e. DNA analysis (for details see table 4). Diagnosis in children is difficult, particularly in the absence of a family history. The vascular type is inherited in an autosomal dominant fashion. Arterial rupture is the most common cause of sudden death and has its peak incidence in the $3^{\text {rd }}$ or $4^{\text {th }}$ decade. Acute abdominal and flank pain is a common presentation of an arterial or intestinal rupture and needs urgent investigation and treatment. Frank et al. showed that the type of COL3A1 mutation is associated with the phenotype and severity: patients with glycine substitutions, splice-site mutations and in-frame insertions-deletions have a more severe phenotype, including digestive events, compared to e.g. mutations leading to non-glycine missense variants or haploinsufficiency, due to a null allele. The latter may delay onset of complications by almost 2 decades. ${ }^{16,17}$ A recent study showed that vEDS is characterized by a high frequency of de novo pathogenic variants, while parental mosaicism was rare. ${ }^{18}$

For women with the vascular type, pregnancy and delivery pose specific risks, which warrant preconceptional counselling with an experienced obstetrician and clinical geneticist. ${ }^{19}$

There is considerable clinical overlap between the vascular type and Loeys-Dietz syndrome type 1 and 2 (OMIM 609192 and 610168 respectively), which are due to TGFBR1 (type 1) and TGFBR2 (type 2) mutations. ${ }^{20}$ Also other aortic aneurysm syndromes, such as Marfan syndrome, Thoracic Aortic Aneurysm and Dissection (TAAD), annulo-aortic ectasia should be included in the differential diagnosis. ${ }^{21}$

The hypermobile EDS, incorporating BJHS, is dominated by generalized joint hypermobility and its possible sequelae, in particular chronic pain, which can be severe and invalidating, and possibly early osteoarthritis. $^{22}$ As said before, the new diagnostic criteria are more strict than the Villefranche criteria and 
the Brighton criteria. ${ }^{4}$ The clinical diagnosis of hypermobile EDS needs the simultaneous presence of 3 criteria: criterion 1 = generalized joint hypermobility, criterion $2=2$ or more of the features $\mathrm{A}, \mathrm{B}$ and $\mathrm{C}(\mathrm{A}=$ systemic manifestations of a more generalized connective tissue disorder; $\mathrm{B}=$ positive family history; $\mathrm{C}=$ musculoskeletal complications) and criterion $3=$ absence of unusual skin fragility and exclusion of alternative diagnosis (for details see table 4). Recently, also cardiovascular dysautonomia (mainly postural tachycardia syndrome = POTS), functional gastrointestinal manifestations, sleep disturbance, fatigue, depression and anxiety disorders have been attributed to hypermobile EDS, but these are at the moment not sufficiently sensitive nor specific. Basically, there is no confirmative laboratory test for the hypermobility type, meaning that it is a purely clinical diagnosis. In 2015, Syx et al. reported linkage to chromosome 8p22-8p21.1 in a 3 generation Belgian family with EDS hypermobility type, whereby whole exome sequencing revealed a possibly involved gene. ${ }^{23} \mathrm{Up}$ to recently, BJHS was considered a separate entity with its own diagnostic criteria. ${ }^{24}$ It was already argued earlier that the hypermobility type and BJHS are in fact one and the same disorder with variable expression. Arguments put forward for this were among others the fact that haploinsufficiency of $T N X-B$, assessed as about half of the normal activity of tenascin-X in blood, and/or heterozygosity for a pathogenic $T N X-B$ mutation, is found both in cases with EDS hypermobility type and cases in whom BJHS is the more likely diagnosis. ${ }^{25}$ Also, a changing phenotype from one diagnosis into the other in one individual and in some pedigrees the occurrence of both diagnoses argued for this statement. ${ }^{26}$

Castori et al. proposed a framework for the classification of joint hypermobility and related syndromes. $^{27}$

The arthrochalasia EDS is also rare, but diagnosable at birth. ${ }^{13}$ Minimal criteria suggestive for arthrochalasia EDS are congenital bilateral hip dislocation plus either skin hyperextensibility or severe generalized joint hypermobility with multiple dislocations/subluxations and at least 2 other minor criteria (for details see table 4). It is inherited in an autosomal dominant fashion. It is due to specific mutations in COL1A1 or COL1A2. Larsen syndrome, which also features congenital luxations, should be in the differential diagnosis.

The dermatosparaxis EDS derives its name from a similar phenotype and biochemical defect in cattle, sheep, and other animals. ${ }^{13}$ It is the EDS type which has the closest resemblance to cutis laxa. However, in cutis laxa there is neither fragility nor bruising. Its mode of inheritance is autosomal recessive. It is one of the rarest of all types and since only very few cases have been described, possibly this type is characterised by other as yet unrecognised - features. Recently, Van Damme et al. expanded the phenotype and suggested new diagnostic criteria. ${ }^{28}$ The New York nosology requires for its diagnosis extreme skin fragility with congenital or postnatal skin tears AND characteristic craniofacial features plus either 1 other major and/or 3 minor criteria (for details see table 4). It is due to bi-allelic mutations in ADAMTS2. The mode of inheritance is autosomal recessive.
The kyphoscoliotic EDS is a rare but severe form of EDS, manifesting itself often at or shortly after birth. ${ }^{13,29}$ The presence of congenital muscle hypotonia AND congenital or early onset kyphoscoliosis plus either generalized joint hypermobility and/or 3 minor criteria (either general or PLODI and FKBPI4 gene-specific) warrants laboratory testing. Kyphoscoliotic EDS is genetically heterogeneous and can be caused by mutations in PLODI and FKBP14. Laboratory tests should start with measurement of the urinary lysyl and hydroxy-lysyl pyridinoline ratio. An increased ratio has a very high degree of sensitivity and specificity for PLODI mutations, but not for FKBP14 mutations (for details and molecular tests: see table 4). The mode of inheritance is autosomal recessive. Because of severe hypotonia, patients very often undergo a full scale neuromuscular work-up, including a muscle biopsy before the diagnosis is established. The differential diagnosis comprises all other causes of severe hypotonia, including neonatal Marfan syndrome.

The even rarer brittle cornea syndrome resembles the kyphoscoliotic type, but is generally milder. ${ }^{13,30}$ Minimal diagnostic criteria are thin cornea with or without rupture plus either at least one other major criterion and/or 3 minor criteria (for details see table 4). It shows a normal urinary lysyl and hydroxy-lysyl pyridinoline ratio, and is characterised by mutations in the genes ZNF469 or PRDM5.

Spondylodysplastic EDS is genetically heterogeneous and is due to bi-allelic mutations in either B4GALT7 (former name progeroid type $1^{31}$ ), B3GALT6 (former name progeroid type $2^{32}$ ) or SLC39A13 (former name spondylocheirodysplastic type $\left.{ }^{33}\right) .{ }^{13}$ There is considerable overlap with kyphoscoliotic EDS. Minimal diagnostic criteria are short stature AND muscle hypotonia plus characteristic radiographic abnormalities and at least 3 other minor criteria (general or gene-specific; see table 4).

The urinary lysysl and hydroxylysyl pyridinoline ratio is moderately increased (to approximately 1 compared to normal values of $\sim 0.2$ ) with HLPC for SLC39A13 mutations. Van Damme et al. described recently 12 patients with bi-allelic B3GALT6 mutations. ${ }^{34}$

The musculocontractural EDS is due to bi-allelic mutations in either CHST14 gene (type 1) or more rarely DSE gene (type 2) and has also considerable clinical overlap with the kyphoscoliotic type. ${ }^{13,35}$ Uehara et al. described spinal involvement in 12 patients with CHST14 related mcEDS. ${ }^{36}$ Minimal diagnostic criteria are at birth or in early childhood congenital multiple contractures AND characteristic craniofacial features, while in adolescence and adulthood these are congenital multiple contractures AND characteristic cutaneous features (for details see table 4).

Myopathic EDS is caused by heterozygous or biallelic mutations in COL12A1. 13,37 Minimal diagnostic criteria are congenital muscle hypotonia and/or muscle atrophy that improves with age plus either one other major criterion and/or three minor criteria (for details see table 4). The phenotype highly overlaps with collagen VI type related myopathies, i.e. Bethlem myopathy and Ullrich Congenital Muscular Dystrophy.

The periodontal EDS has some overlap with the classical type, but has progressive and aggressive 
periodontitis as a distinguishing feature. ${ }^{13}$ Minimal diagnostic criteria are severe, intractable periodontitis of early onset (childhood or adolescence) OR lack of attached gingiva plus at least 2 other major criteria and one minor criterion (for details see table 4). In 2016, it was found that gain-of-function mutations in the $C 1 R$ gene or the $C 1 S$ gene, encoding serine proteinases, cause periodontal EDS. ${ }^{38}$ Recently, leukencephalopathy and peri-implant disease were described as additional features of pEDS. ${ }^{39,40}$

In 2016, bi-allelic $A E B P 1$ mutations were described in an autosomal recessive EDS variant, featuring joint hypermobility with joint dislocations, hyperextensible, translucent and redundant skin, poor wound healing with abnormal scarring, easy bruising and gastrointestinal, urogenital, cardiovascular and skeletal abnormalities. Its features overlap with several EDS types, particularly cEDS, mcEDS and spEDS. So far, 8 patients with biallelic $A E B P 1$ mutations have been described. AEBPI encodes ACLP, that associates with collagens in the extracelleular matrix (ECM) and is highly expressed in collagen rich tissues like skin, vasculature and connective tissues. ${ }^{41,42,43,44}$ In OMIM it can be found under 618000, named EDS classic-like, 2. This new EDS variant is not added in any of the tables 1,2, and 4 .

The former EDS type V (X-linked) has been described in only 2 families and is not any longer accepted as belonging to the EDS spectrum; the same holds true for the former fibronectin deficient type X, familial articular hypermobility EDS XI and Filamin A related EDS with heterotopia. The former type IX is an $\mathrm{X}$-linked cutis laxa disorder and is renamed occipital horn syndrome; it is due to mutations in the gene ATP7A, the same gene as is mutated in Menkes syndrome (disorder of copper metabolism).

For further reading, the excellent reviews by Malfait et al. and Byers and Murray are highly recommended. ${ }^{4,45}$ The whole March 2017 issue of the American Journal of Medical Genetics Part C, Seminars in Medical Genetics provided a very good update not only about EDS nosology and diagnostic criteria, but also about management aspects of the various types of EDS. Management for EDS patients preferably is provided by multidisciplinary teams in expertise centres. However, in a recent literature study concerning clinical practice guidelines specifically addressed to EDS the total absence of such guidelines was noted and many clinician and patient unmet needs were identified. ${ }^{46}$

Joint hypermobility is a symptom of large variety of syndromes. Among these, one finds - not surprisingly other heritable connective tissue disorders like cutis laxa, osteogenesis imperfecta, Stickler syndrome, LoeysDietz syndrome and Marfan syndrome, but also skeletal dysplasias, inborn errors of metabolism, neuromuscular disorders, chromosomal abnormalities and syndromes like Larsen syndrome, Fragile X syndrome and LangerGiedion syndrome.

\section{HOW TO REACH THE DIAGNOSIS EHLERS- DANLOS SYNDROME, INCLUDING CORRECT TYPING?}

Like always in clinical practice, the results of history taking, including a family history, and physical examination are the basis for planning additional investigations and finally reaching a diagnosis. Additional investigations are often biochemical as a first screen, followed by targeted DNA analysis. However, with the introduction of new DNA technologies, like next generation sequencing (NGS), rapid search for the disease causing mutation by molecular analysis of all known EDS genes ("the EDS panel") at once has become possible. This is already standard routine diagnostic practice in many laboratories and will become routine in all in the near future. Copy number variation analysis for large deletions and duplications has also a place in the molecular analysis in cases where NGS did not reveal a mutation in AD types and only one mutation in AR types, while whole exome sequencing and whole genome sequencing will be indicated in the search for new types when all tests are negative.

As history taking and physical examination in relation to EDS are very important, these will be discussed below.

Good history taking starts with identifying the exact symptoms and complaints, which compelled the patient to see a physician: when and how did they start and evolve, how were they treated (what were the results, what was advised/prescribed and by whom?). Specific questions should elucidate the presence or absence of:

- Hypermobility and/or (sub)luxations. If (sub)luxation occurred: which joint(s) was/were involved, how often did it occur, was it spontaneous (also the first time) and painful? Was it seen/treated by doctors? If necessary also the Five-Point Questionnaire (5PQ; see footnote in table 4). Contractures? Congenital hip dislocation $?^{47,48}$

- Painful joints. ${ }^{49}$ If so: which ones, when, under which circumstances, exercise related, warm and swollen, if so, for how long? Use of analgesics? Sprains? What are the major limitations in daily life?

Temporomandibular joint problems. ${ }^{50}$

- Problems with bursae/tendons. (Spontaneous) fractures.

- Skin fragility and abnormal wound healing with wide atrophic scars.

- Surgery, e.g. for inguinal hernia. If so: complications?

- $\quad$ Easy bruising and/or abnormal menstrual bleeding.

- Abnormal exercise tolerance and/or fatigue. ${ }^{51}$ Sports performed? Type of work: blue or white collar?

- Pneumothorax?

- Cardiac problems? Cardiovascular autonomic dysfunction? ${ }^{52}$

- Genito-urinary tract problems, e.g. uterine prolapse, voiding dysfunction.

- Gastro-intestinal tract problems, e.g. constipation, diverticula, rectal prolapse. ${ }^{53}$

- For female patients with children: pregnancy and delivery problems. ${ }^{19}$

- Rupture of internal organs (arteries, lungs, intestines, spleen, uterus).

- Psychiatric problems, like anxiety, depression, ADHD $?^{54}$

Neurological problems $?^{55,56}$ Headache? Migraine?

- Eye problems, e.g. refractive errors, abnormal vision.

Hearing? 


\section{Growth?}

Motor and cognitive development?

Dental problems?

- Miscellaneous: Gingivitis? Varicose veins? Abnormal effect of local anaesthesia?

The family history includes drawing a three generation pedigree with specific enquiry regarding hypermobility, easy bruising, abnormal scarring, arterial dissections and organ ruptures.

The physical examination is focused on signs relevant for connective tissue disorders:

- $\quad$ Build and biometry: height, weight, span and others when indicated. Marfanoid?

- Facial features: among others, Gorlin sign (ability to touch the tip of the nose with the tip of tongue)? High palate? Absence of subcutaneous fat? Prominent eyes? Thin, "pinched" nose? Normal earlobes? Epicanthic folds? Low-set ears? Midfacial hypoplasia? Micrognathia? Downslanting palpebral fissures? Gingival recession?

- Teeth: dental crowding? Discoloured? Dysplastic? Periodontitis?

- Thorax: deformity?

- Back: (kypho)scoliosis?

- Extremities: Beighton score; arachnodactyly (wrist and thumb sign)? (Sub)luxations? Brachydactyly? Contractures? Flat feet? Joints? Muscle strength? Hallux valgus?

- Skin: extensibility? Texture? Thickness and venous pattern? Striae distensae? Varicose veins? Piezogenic papules? Molluscoid pseudotumors? Spheroids? Scars? Herniae?

- Eyes: blue sclerae? Microcornea? Strabismus? Clouded cornea? Glaucoma? Scleral/ocular fragility? Keratoconus?

- Neurological examination: muscle weakness? Reduction in vibration sense? Reduction of tendon reflexes?

After history taking, a differential diagnosis will be established, on which basis additional investigations, such as biochemical and/or DNA analysis in blood and/or cultured fibroblasts, derived from a skin biopsy, are planned, if clinically relevant and available for the suspected type(s). Morphological examination of a skin biopsy is of limited value, except in some types, particularly in dermatosparaxis EDS. On indication, the patient will be referred to an ophthalmologist, cardiologist, orthopaedic surgeon, neurologist and/or others.

DNA analyses are available as diagnostic services in most of the high and middle income countries. As already indicated, there is no DNA test available for hypermobile EDS. If there is any reason to believe the phenotype could be the classical-like, tenascin-X deficient type, then there is an indication to perform tenascin- $X$ analysis in serum. If there is suspicion of vascular EDS, the threshold to do DNA analysis should be very low, because of the consequences of that diagnosis in terms of management and genetic counselling. For some of the other EDS types the same holds true, because of their severity, rareness, overlapping features with other EDS types and/or different modes of inheritance. In fact, for definite diagnosis molecular confirmation is needed for all types, except the hypermobile type.

\section{GENETIC COUNSELLING}

Since all the disorders which have been discussed have a genetic background, genetic counselling is an indispensable part of the management of patients and their families. During genetic counselling, information will be given about the mode of inheritance, recurrence risk, variability and penetrance of the disorder, the possibilities of prenatal diagnosis and diagnosis in relatives at risk and management. Prenatal diagnosis and diagnosis in relatives at risk is only possible if the causative DNA defect is known. A social worker should be available to assist whenever a need is perceived or requested. When there is a patient/parent support group, patients/parents should be informed. In case of a proband of non-EDS parents, it is essential to differentiate between an autosomal dominant (e.g. classical type) and an autosomal recessive type (e.g. classical-like, tenascindeficient type): in the classical type the recurrence risk for a next child of these non-EDS parents is low (less than $1 \%)$ and for a child of the affected patient high (50\%), while in the tenascin-deficient type the recurrence risk for a next child is high (25\%) and for a child of the affected patient generally low (1\% or less). It is important to be aware of the possibility of parental mosaicism in cases which are apparently de novo. ${ }^{18}$

\section{CONCLUSION}

EDS is a fairly common, clinically and genetically heterogeneous disorder, belonging to the heritable disorders of connective tissue. The latest official classification of 2017 recognized 13 types. Since then another variant has been described and there is still room for the identification of other types. In individual patients it is a challenge to correctly type EDS, even after careful history taking and physical examination. Often a molecular diagnosis is needed for correct typing and NGS is thereby of great help. Management is preferably provided by a multidisciplinary team in expert centres. Genetic counselling is an integral part of its management.

\section{ACKNOWLEDGMENT}

This chapter is adapted from Jacobs JWG, Cornelissens LJM, Veenhuizen MC, Hamel BCJ, eds. Ehlers-Danlos syndrome: a multidisciplinary approach. Amsterdam: IOS Press, 2018: pages 5-31 with permission from IOS Press. This is a freely available ebook, ISBN 978-1-61499-878-5 (online). https://www.iospress.nl/book/ehlers-danlos-syndromea-multidisciplinary-approach/. 
Table 4 Diagnostic criteria, minimal criteria and verification of Ehlers-Danlos syndromes (data extracted from ${ }^{4}$ )

\begin{tabular}{|c|c|c|c|c|}
\hline $\begin{array}{l}\text { Types of } \\
\text { EDS }\end{array}$ & $\begin{array}{l}\text { Major diagnostic } \\
\text { criteria }\end{array}$ & Minor diagnostic criteria & $\begin{array}{l}\text { Suggestive minimal } \\
\text { criteria for diagnosis }\end{array}$ & $\begin{array}{l}\text { Verification of clinical } \\
\text { diagnosis }\end{array}$ \\
\hline $\begin{array}{l}\text { Classical } \\
\text { EDS }\end{array}$ & $\begin{array}{l}\text { Skin } \\
\text { hyperextensibility and } \\
\text { atrophic scars } \\
\text { Generalized joint } \\
\text { hypermobility }\end{array}$ & $\begin{array}{l}\text { Easy bruising } \\
\text { Smooth, velvety skin } \\
\text { Skin fragility (or traumatic } \\
\text { splitting) } \\
\text { Molluscoid pseudotumors } \\
\text { Subcutaneous spheroids } \\
\text { Hernia (or history thereof) } \\
\text { Epicanthic folds } \\
\text { Complications of joint } \\
\text { hypermobility e.g. sprains, } \\
\text { (sub)luxations, pain, pes planus } \\
\text { First degree relative fulfilling } \\
\text { clinical criteria }\end{array}$ & $\begin{array}{l}\text { Skin } \\
\text { hyperextensibility and } \\
\text { atrophic scars, plus } \\
\text { either generalized } \\
\text { joint hypermobility } \\
\text { and/or } 3 \text { minor criteria }\end{array}$ & $\begin{array}{l}\text { Molecular screening of a } \\
\text { targeted EDS gene panel, } \\
\text { including at least COL5A1, } \\
\text { COL5A2,COL1A1 and } \\
\text { COL1A2. } \\
\text { When not available } \\
\text { transmission electron } \\
\text { microscopy (TEM) of skin } \\
\text { biopsy (collagen flowers) } \\
\text { might be supportive }\end{array}$ \\
\hline $\begin{array}{l}\text { Classical- } \\
\text { like EDS }\end{array}$ & $\begin{array}{l}\text { Skin } \\
\text { hyperextensibility } \\
\text { with velvety skin } \\
\text { texture and absence of } \\
\text { atrophic scarring } \\
\text { Generalized joint } \\
\text { hypermobility with or } \\
\text { without recurrent } \\
\text { dislocations } \\
\text { Easy bruisable } \\
\text { skin/spontaneous } \\
\text { ecchymoses }\end{array}$ & $\begin{array}{l}\text { Foot deformities: broad/plump } \\
\text { forefoot, brachydactyly, pes } \\
\text { planus, hallux valgus, } \\
\text { piezogenic papules } \\
\text { Edema of legs } \\
\text { Mild proximal and distal } \\
\text { muscle weakness } \\
\text { Axonal polyneuropathy } \\
\text { Atrophy of hand and foot } \\
\text { muscles } \\
\text { Acrogeric hands, mallet } \\
\text { finger(s), clinodactyly, } \\
\text { brachydactyly } \\
\text { Vaginal/uterus/rectal prolapse }\end{array}$ & $\begin{array}{l}\text { All } 3 \text { major criteria } \\
\text { and a family history } \\
\text { compatible with } \\
\text { autosomal recessive } \\
\text { inheritance }\end{array}$ & $\begin{array}{l}\text { Molecular analysis of } T N X B \\
\text { gene. If necessary CNV } \\
\text { analysis for deletions. } \\
\text { Complete absence of TNX in } \\
\text { serum. }\end{array}$ \\
\hline $\begin{array}{l}\text { Cardiac- } \\
\text { valvular } \\
\text { EDS }\end{array}$ & $\begin{array}{l}\text { Severe progressive } \\
\text { cardiac-valvular } \\
\text { problems } \\
\text { Skin } \\
\text { hyperextensibility, } \\
\text { atrophic scars, thin } \\
\text { skin, easy bruising } \\
\text { Generalized or small } \\
\text { joints hypermobility }\end{array}$ & $\begin{array}{l}\text { Inguinal hernia } \\
\text { Pectus deformity (mostly } \\
\text { excavatum) } \\
\text { Joint dislocations } \\
\text { Foot deformities: pes } \\
\text { (plano)valgus, hallux valgus }\end{array}$ & $\begin{array}{l}\text { Severe progressive } \\
\text { cardiac-valvular } \\
\text { problems AND family } \\
\text { history compatible } \\
\text { with AR inheritance } \\
\text { plus either one other } \\
\text { major criterion and/or } \\
\text { at least } 2 \text { minor }\end{array}$ & $\begin{array}{l}\text { Molecular screening by } \\
\text { Sanger sequencing of } \\
\text { COL1A2 or targeted } \\
\text { resequencing of a EDS gene } \\
\text { panel. If necessary CNV } \\
\text { analysis for deletions and } \\
\text { duplications. } \\
\text { Total absence of (pro) } \alpha 2(\mathrm{I}) \\
\text { with SDS PAGE }\end{array}$ \\
\hline $\begin{array}{l}\text { Vascular } \\
\text { EDS }\end{array}$ & $\begin{array}{l}\text { Family history of } \\
\text { vEDS with molecular } \\
\text { confirmation } \\
\text { Arterial rupture at } \\
\text { young age } \\
\text { Spontaneous sigmoid } \\
\text { colon perforation } \\
3^{\text {rd }} \text { Trimester uterine } \\
\text { rupture } \\
\text { Carotid-cavernous } \\
\text { sinus fistula } \\
\text { (Last 3: in the absence } \\
\text { of other explanations) }\end{array}$ & $\begin{array}{l}\text { Bruising without trauma and/or } \\
\text { in unusual sites (cheeks, back) } \\
\text { Thin, translucent skin with } \\
\text { increased venous visibility } \\
\text { Characteristic facial appearance } \\
\text { Spontaneous pneumothorax } \\
\text { Acrogeria } \\
\text { Talipes equinovarus } \\
\text { Congenital hip dislocation } \\
\text { Hypermobility of small joints } \\
\text { Tendon and muscle rupture } \\
\text { Keratoconus } \\
\text { Gingival recession and fragility } \\
\text { Early onset varicose veins }(<30 \\
\text { years and nulliparous if female) }\end{array}$ & $\begin{array}{l}\text { A family history of } \\
\text { vEDS, } \\
\text { rupture/dissection }<40 \\
\text { years, unexplained } \\
\text { sigmoid colon rupture } \\
\text { or spontaneous } \\
\text { pneumothorax in the } \\
\text { presence of other } \\
\text { features consistent } \\
\text { with vEDS, a } \\
\text { combination of other } \\
\text { minor criteria should } \\
\text { all lead to verifying } \\
\text { diagnostic tests. }\end{array}$ & $\begin{array}{l}\text { Molecular screening by } \\
\text { Sanger sequencing of } \\
C O L 3 A 1 \text { or targeted } \\
\text { resequencing of a EDS gene } \\
\text { panel, including COL } 3 A 1 \text { and } \\
\text { COL1A1. } \\
\text { If necessary CNV analysis for } \\
\text { deletions and duplications. }\end{array}$ \\
\hline $\begin{array}{l}\text { Hypermob } \\
\text { ile EDS }\end{array}$ & $\begin{array}{l}\text { Generalized joint } \\
\text { hypermobility (GHJ) } \\
\text { assessed by Beighton } \\
\text { score } \\
\geq 6 \text { for prepubertal } \\
\text { children and } \\
\text { adolescents } \\
\geq 5 \text { for pubertal men } \\
\text { and women up to the } \\
\text { age of } 50 \\
\geq 4 \text { for those }>50 \\
\text { years of age } \\
\text { If the Beighton score } \\
\text { is } 1 \text { point below the } \\
\text { age- and sex-specific }\end{array}$ & $\begin{array}{l}\text { A: systemic manifestations of a } \\
\text { more generalized connective } \\
\text { tissue disorder } \\
\text { 1. unusually soft or velvety skin } \\
\text { 2. mild skin hyperextensibility } \\
\text { 3. unexplained striae distensae } \\
\text { 4. bilateral piezogenic papules } \\
\text { (heel) } \\
\text { 5. recurrent or multiple } \\
\text { abdominal hernias } \\
\text { 6. atrophic scarring at } 2 \text { or more } \\
\text { sites without truly papyraceous } \\
\text { and/or hemosideric scars } \\
\text { 7. pelvic floor, rectal and/or } \\
\text { uterine prolapse in children, }\end{array}$ & $\begin{array}{l}\text { 1. Generalized joint } \\
\text { hypermobility AND } \\
\text { 2. Two or more } \\
\text { among features A-C } \\
(\mathrm{A}+\mathrm{B}, \mathrm{A}+\mathrm{C}, \mathrm{B}+\mathrm{C} \text {, } \\
\mathrm{A}+\mathrm{B}+\mathrm{C}) \text { must be } \\
\text { present } \\
\text { A: total of } 5 \text { must be } \\
\text { present } \\
\text { B: must be present } \\
\text { C: } 1 \text { or more must be } \\
\text { present } \\
\text { AND } \\
\text { 3. absence of unusual } \\
\text { skin fragility AND }\end{array}$ & $\begin{array}{l}\text { Not possible; hEDS is a } \\
\text { clinical diagnosis. } \\
\text { Sleep disturbance, fatigue, } \\
\text { postural orthostatic } \\
\text { tachycardia, functional } \\
\text { gastro-intestinal disorders, } \\
\text { dysautonomia, anxiety and } \\
\text { depression are not part of the } \\
\text { diagnostic criteria, but its } \\
\text { presence may prompt } \\
\text { consideration of hEDS in the } \\
\text { differential diagnosis. }\end{array}$ \\
\hline
\end{tabular}




\begin{tabular}{|c|c|c|c|c|}
\hline & $\begin{array}{l}\text { cut-off AND the 5- } \\
\text { point questionnaire } \\
(5 \mathrm{PQ})^{*} \text { is positive then } \\
\text { a diagnosis of GJH } \\
\text { can be made }\end{array}$ & $\begin{array}{l}\text { men or nulliparous women } \\
\text { without obesity or other } \\
\text { explanation } \\
\text { 8. dental crowding and } \\
\text { high/narrow palate } \\
\text { 9. arachnodactyly (bilateral } \\
\text { positive wrist or thumb sign) } \\
\text { 10. arm span-to-height } \geq 1.05 \\
\text { 11. mitral valve prolapse (strict } \\
\text { echocardiographic criteria) } \\
\text { 12. aortic root dilatation with Z- } \\
\text { score }>+2 \\
\text { B: one or more first degree } \\
\text { relatives independently meeting } \\
\text { the criteria for hEDS } \\
\text { C: musculoskeletal } \\
\text { complications } \\
1 . \text { pain in } 2 \text { or more limbs, } \\
\text { recurring daily for at least } 3 \\
\text { months } \\
2 . \text { chronic widespread pain for } \\
\geq 3 \text { months } \\
3 \text {. recurrent joint dislocations or } \\
\text { frank joint instability in the } \\
\text { absence of trauma (a or b) } \\
\text { a. } 3 \text { or more dislocations in the } \\
\text { same joint or } 2 \text { or more } \\
\text { dislocations in } 2 \text { different joints } \\
\text { occurring at different times } \\
\text { b. medical confirmation of joint } \\
\text { instability at } 2 \text { or more sites }\end{array}$ & $\begin{array}{l}\text { exclusion of other } \\
\text { heritable and acquired } \\
\text { connective tissue } \\
\text { disorders, including } \\
\text { autoimmune } \\
\text { rheumatologic } \\
\text { disorders\# AND } \\
\text { exclusion of } \\
\text { alternative diagnoses } \\
\text { e.g. neuromuscular } \\
\text { disorders, other } \\
\text { Heritable Connective } \\
\text { Tissue Disorders, and } \\
\text { skeletal dysplasias }\end{array}$ & \\
\hline $\begin{array}{l}\text { Arthrocha } \\
\text { lasia EDS }\end{array}$ & $\begin{array}{l}\text { Congenital bilateral } \\
\text { hip dislocation } \\
\text { Severe generalized } \\
\text { joint hypermobility } \\
\text { with multiple } \\
\text { dislocations/ } \\
\text { subluxations } \\
\text { Skin } \\
\text { hyperextensibility }\end{array}$ & $\begin{array}{l}\text { Muscle hypotonia } \\
\text { Kyphoscoliosis } \\
\text { Mild osteopenia (X-ray) } \\
\text { Tissue fragility, including } \\
\text { atrophic scars } \\
\text { Easy bruisable skin }\end{array}$ & $\begin{array}{l}\text { Congenital bilateral } \\
\text { hip dislocation plus } \\
\text { either skin } \\
\text { hyperextensibility or } \\
\text { severe generalized } \\
\text { joint hypermobility } \\
\text { with multiple } \\
\text { dislocations/ } \\
\text { subluxations and at } \\
\text { least } 2 \text { other minor } \\
\text { criteria }\end{array}$ & $\begin{array}{l}\text { Molecular screening by } \\
\text { Sanger sequencing of } \\
C O L 1 A 1 / A 2 \text { or targeted } \\
\text { resequencing of a EDS gene } \\
\text { panel, including COL1A1/A2. } \\
\text { If necessary CNV analysis for } \\
\text { deletions and duplications. } \\
\text { Supportive might be SDS } \\
\text { PAGE analysis of cultured } \\
\text { skin fibroblasts and TEM of } \\
\text { skin biopsies }\end{array}$ \\
\hline $\begin{array}{l}\text { Dermatos } \\
\text { paraxis } \\
\text { EDS }\end{array}$ & $\begin{array}{l}\text { Extreme skin fragility } \\
\text { with congenital or } \\
\text { postnatal skin tears } \\
\text { Characteristic } \\
\text { craniofacial features } \\
\text { Redundant, almost lax } \\
\text { skin, } \\
\text { Increased palmar } \\
\text { wrinkling } \\
\text { Severe bruisability } \\
\text { Umbilical hernia } \\
\text { Postnatal growth } \\
\text { retardation } \\
\text { Short limbs, hands } \\
\text { and feet } \\
\text { Perinatal } \\
\text { complications due to } \\
\text { connective tissue } \\
\text { fragility }\end{array}$ & $\begin{array}{l}\text { Soft and doughy skin texture } \\
\text { Skin hyperextensibility } \\
\text { Atrophic scars } \\
\text { Generalized joint hypermobility } \\
\text { Complications of visceral } \\
\text { fragility (bladder/diaphragmatic } \\
\text { rupture, rectal prolapse) } \\
\text { Delayed motor development } \\
\text { Osteopenia } \\
\text { Hirsutism } \\
\text { Tooth abnormalities } \\
\text { Refractive errors (myopia, } \\
\text { astigmatism) } \\
\text { Strabismus }\end{array}$ & $\begin{array}{l}\text { Extreme skin fragility } \\
\text { with congenital or } \\
\text { postnatal skin tears } \\
\text { AND characteristic } \\
\text { craniofacial features } \\
\text { plus either } 1 \text { other } \\
\text { major and/or } 3 \text { minor } \\
\text { criteria }\end{array}$ & $\begin{array}{l}\text { Molecular screening by } \\
\text { Sanger sequencing of } \\
\text { ADAMTS2 or targeted } \\
\text { resequencing of a EDS gene } \\
\text { panel, including } A D A M T S 2 \text {. } \\
\text { If necessary CNV analysis for } \\
\text { deletions and duplications. } \\
\text { Supportive might be SDS } \\
\text { PAGE analysis of cultured } \\
\text { skin fibroblasts and TEM of } \\
\text { skin biopsies }\end{array}$ \\
\hline $\begin{array}{l}\text { Kyphosco } \\
\text { liotic EDS }\end{array}$ & $\begin{array}{l}\text { Congenital muscle } \\
\text { hypotonia } \\
\text { Congenital or early } \\
\text { onset kyphoscoliosis } \\
\text { Generalized joint } \\
\text { hypermobility with } \\
\text { multiple dislocations/ } \\
\text { subluxations }\end{array}$ & $\begin{array}{l}\text { Skin hyperextensibility } \\
\text { Easy bruisable skin } \\
\text { Rupture/aneurysm of a } \\
\text { medium-sized artery } \\
\text { Osteopenia/osteoporosis } \\
\text { Blue sclerae } \\
\text { Hernia (umbilical or inguinal) } \\
\text { Pectus deformity } \\
\text { Marfanoid habitus } \\
\text { Talipes equinovarus }\end{array}$ & $\begin{array}{l}\text { Congenital muscle } \\
\text { hypotonia AND } \\
\text { congenital or early } \\
\text { onset kyphoscoliosis } \\
\text { plus either } \\
\text { generalized joint } \\
\text { hypermobility and/or } \\
3 \text { minor criteria } \\
\text { (general or gene- } \\
\text { specific) }\end{array}$ & $\begin{array}{l}\text { Increased Dpyr/pyr (= } \\
\text { LP/HP) ratio in urine by } \\
\text { HPLC is highly sensitive for } \\
\text { PLOD1 kEDS. Molecular } \\
\text { analysis: MLPA of PLOD1 } \\
\text { (duplication); if negative } \\
\text { MLPA, targeted resequencing } \\
\text { of a EDS gene panel, } \\
\text { including PLOD1 and } \\
\text { FKBP14, but also ZNF469, }\end{array}$ \\
\hline
\end{tabular}




\begin{tabular}{|c|c|c|c|c|}
\hline & & $\begin{array}{l}\text { Refractive errors (myopia, } \\
\text { hypermetropia) } \\
\text { PLOD1 specific minor criteria } \\
\text { Skin fragility (e.g. atrophic } \\
\text { scarring, friable skin) } \\
\text { Scleral/ocular fragility/rupture } \\
\text { Microcornea } \\
\text { Facial dysmorphology (e.g. } \\
\text { low-set ears, epicanthal folds, } \\
\text { down-slanting fissures, } \\
\text { synophrys, high palate) } \\
\text { FKBP14 specific minor } \\
\text { criteria } \\
\text { Congenital sensorineural, } \\
\text { conductive or mixed hearing } \\
\text { impairment } \\
\text { Follicular hyperkeratosis } \\
\text { Muscle atrophy } \\
\text { Bladder diverticula }\end{array}$ & & $\begin{array}{l}\text { PRDM5, B4GALT7, } \\
\text { B3GALT6, SLC39A13, } \\
\text { CHST14 and DSE, because of } \\
\text { overlapping phenotypes. } \\
\text { If necessary CNV analysis for } \\
\text { deletions and duplications. } \\
\text { Supportive might be TEM of } \\
\text { skin biopsies }\end{array}$ \\
\hline $\begin{array}{l}\text { Brittle } \\
\text { Cornea } \\
\text { syndrome }\end{array}$ & $\begin{array}{l}\text { Thin cornea with or } \\
\text { without rupture } \\
\text { Early onset } \\
\text { progressive } \\
\text { keratoconus } \\
\text { Early onset } \\
\text { progressive } \\
\text { keratoglobus } \\
\text { Blue sclerae }\end{array}$ & $\begin{array}{l}\text { Enucleation or corneal scarring } \\
\text { Progressive loss of corneal } \\
\text { stroma depth } \\
\text { High myopia } \\
\text { Retinal detachment } \\
\text { Progressive high frequency } \\
\text { often mixed deafness } \\
\text { Hypercompliant tympanic } \\
\text { membranes } \\
\text { Developmental hip dysplasia } \\
\text { Mild hypotonia in infancy } \\
\text { Scoliosis } \\
\text { Arachnodactyly } \\
\text { Hypermobility of distal joints } \\
\text { Pes planus, hallux valgus } \\
\text { Mild finger contractures (esp. } \\
5^{\text {th }} \text { ) }\end{array}$ & $\begin{array}{l}\text { Thin cornea with or } \\
\text { without rupture plus } \\
\text { either at least one } \\
\text { other major criterion } \\
\text { and/or } 3 \text { minor criteria }\end{array}$ & $\begin{array}{l}\text { Molecular screening by } \\
\text { targeted resequencing of a } \\
\text { EDS gene panel, including } \\
\text { ZNF469 and PRDM5, but } \\
\text { also PLOD1, FKBP14, } \\
B 4 G A L T 7, B 3 G A L T 6 \text {, } \\
\text { SLC39A13, CHST14 and } \\
D S E \text {, because of overlapping } \\
\text { phenotypes. } \\
\text { If necessary CNV analysis for } \\
\text { deletions and duplications. }\end{array}$ \\
\hline $\begin{array}{l}\text { Spondylo } \\
\text { dysplastic } \\
\text { EDS }\end{array}$ & $\begin{array}{l}\text { Progressive short } \\
\text { stature } \\
\text { Muscle hypotonia } \\
\text { (ranging severe } \\
\text { congenital to mild } \\
\text { later-onset) } \\
\text { Bowing of limbs }\end{array}$ & $\begin{array}{l}\text { Skin hyperextensibility, soft } \\
\text { doughy, thin translucent skin } \\
\text { Pes planus } \\
\text { Delayed motor development } \\
\text { Osteopenia } \\
\text { Delayed cognitive development } \\
\text { B4GALT7 specific minor } \\
\text { criteria } \\
\text { Radioulnar synostosis } \\
\text { Bilateral elbow contractures or } \\
\text { limited elbow movement } \\
\text { Generalized joint hypermobility } \\
\text { Single transverse palmar crease } \\
\text { Characteristic facial features } \\
\text { Characteristic radiographic } \\
\text { findings } \\
\text { Severe hypermetropia } \\
\text { Clouded cornea } \\
\text { B3GALT6 specific minor } \\
\text { criteria } \\
\text { Kyphoscoliosis } \\
\text { Joint hypermobility, generalized } \\
\text { or restricted to distal joints } \\
\text { Joint contractures (esp. hands) } \\
\text { Peculiar fingers (e.g. slender, } \\
\text { tapered, spatulate, broad distal } \\
\text { phalanges) } \\
\text { Talipes equinovarus } \\
\text { Characteristic facial features } \\
\text { Tooth discoloration, dysplastic } \\
\text { teeth } \\
\text { Characteristic radiographic } \\
\text { findings } \\
\text { Osteoporosis (spontaneous } \\
\text { fractures) }\end{array}$ & $\begin{array}{l}\text { Short stature AND } \\
\text { muscle hypotonia } \\
\text { plus characteristic } \\
\text { radiographic } \\
\text { abnormalities and at } \\
\text { least } 3 \text { other minor } \\
\text { criteria (general or } \\
\text { gene-specific) }\end{array}$ & $\begin{array}{l}\text { Molecular screening by } \\
\text { targeted resequencing of a } \\
\text { EDS gene panel, including } \\
B 4 G A L T 7, B 3 G A L T 6 \text { and } \\
S L C 39 A 13 \text { but also } P L O D 1, \\
F K B P 14, Z N F 469, \text { PRDM5, } \\
C H S T 14 \text { and } D S E \text {, because of } \\
\text { overlapping phenotypes. } \\
\text { If necessary CNV analysis for } \\
\text { deletions and duplications. } \\
\text { GAG deficiency with } \\
\text { B4GALT7 and B3GALT6 } \\
\text { mutations in cultured } \\
\text { fibroblasts. } \\
\text { Moderately increased LP/HP } \\
\text { ratio (to approximately } 1 \\
\text { compared to normal values of } \\
\sim 0.2) \text { with HLPC for } \\
\text { SLC39A13 mutations. }\end{array}$ \\
\hline
\end{tabular}




\begin{tabular}{|c|c|c|c|c|}
\hline & & $\begin{array}{l}\text { Ascending aortic aneurysm } \\
\text { Lung hypoplasia, restrictive } \\
\text { lung disease } \\
\text { SLC39A13 specific minor } \\
\text { criteria } \\
\text { Protuberant eyes with bluish } \\
\text { sclerae } \\
\text { Hands with finely wrinkled } \\
\text { palms } \\
\text { Atrophy of thenar muscles, } \\
\text { tapering fingers } \\
\text { Hypermobility of distal joints } \\
\text { Characteristic radiographic } \\
\text { findings }\end{array}$ & & \\
\hline $\begin{array}{l}\text { Musculoc } \\
\text { ontractura } \\
1 \mathrm{EDS}\end{array}$ & $\begin{array}{l}\text { Congenital multiple } \\
\text { contractures } \\
\text { (adduction-flexion } \\
\text { and/or clubfoot) } \\
\text { Characteristic } \\
\text { craniofacial features } \\
\text { Characteristic } \\
\text { cutaneous features } \\
\text { (hyperextensibility, } \\
\text { bruising, fragility, } \\
\text { atrophic scars, } \\
\text { increased palmar } \\
\text { wrinkling) }\end{array}$ & $\begin{array}{l}\text { Recurrent/chronic dislocations } \\
\text { Pectus deformities (flat, } \\
\text { excavatum) } \\
\text { (Kypho)scoliosis } \\
\text { Tapering, slender, cylindrical } \\
\text { fingers } \\
\text { Progressive talipes deformities } \\
\text { (valgus, planus, cavum) } \\
\text { Large subcutaneous hematomas } \\
\text { Chronic constipation } \\
\text { Colonic diverticula } \\
\text { Pneumo(hemo)thorax } \\
\text { Nephro/cystolithiasis } \\
\text { Hydronephrosis } \\
\text { Cryptorchidism } \\
\text { Strabismus } \\
\text { Refractive errors (myopia, } \\
\text { astigmatism) } \\
\text { Glaucoma/elevated intraocular } \\
\text { pressure }\end{array}$ & $\begin{array}{l}\text { At birth or in early } \\
\text { childhood } \\
\text { Congenital multiple } \\
\text { contractures AND } \\
\text { characteristic } \\
\text { craniofacial features } \\
\text { In adolescence and } \\
\text { adulthood } \\
\text { Congenital multiple } \\
\text { contractures AND } \\
\text { characteristic } \\
\text { cutaneous features }\end{array}$ & $\begin{array}{l}\text { Molecular screening by } \\
\text { targeted resequencing of a } \\
\text { EDS gene panel, including } \\
C H S T 14 \text { and } D S E \text { but also } \\
P L O D 1, F K B P 14, Z N F 469, \\
P R D M 5, B 4 G A L T 7, \\
B 3 G A L T 6 \text { and } S L C 39 A 13, \\
\text { because of overlapping } \\
\text { phenotypes. } \\
\text { If necessary CNV analysis for } \\
\text { deletions and duplications. }\end{array}$ \\
\hline $\begin{array}{l}\text { Myopathi } \\
\text { c EDS }\end{array}$ & $\begin{array}{l}\text { Congenital muscle } \\
\text { hypotonia and/or } \\
\text { muscle atrophy that } \\
\text { improves with age } \\
\text { Proximal joint } \\
\text { contractures (knee, } \\
\text { hip, elbow) } \\
\text { Hypermobility of } \\
\text { distal joints }\end{array}$ & $\begin{array}{l}\text { Soft, doughy skin } \\
\text { Atrophic scarring } \\
\text { Delayed motor developmental } \\
\text { Myopathy on muscle biopsy }\end{array}$ & $\begin{array}{l}\text { Congenital muscle } \\
\text { hypotonia and/or } \\
\text { muscle atrophy that } \\
\text { improves with age } \\
\text { plus either one other } \\
\text { major criterion and/or } \\
\text { three minor criteria }\end{array}$ & $\begin{array}{l}\text { Molecular screening by } \\
\text { targeted resequencing of a } \\
\text { EDS gene panel, including } \\
\text { COL12A1, and } \\
\text { COL6A1/A2/A3, because of } \\
\text { overlapping phenotypes } \\
\text { (Bethlem and Ullrich). } \\
\text { If necessary CNV analysis for } \\
\text { deletions and duplications. }\end{array}$ \\
\hline $\begin{array}{l}\text { Periodont } \\
\text { al EDS }\end{array}$ & $\begin{array}{l}\text { Severe, intractable } \\
\text { periodontitis of early } \\
\text { onset (childhood or } \\
\text { adolescence) } \\
\text { Lack of attached } \\
\text { gingiva } \\
\text { Pretibial plaques } \\
\text { First degree relative } \\
\text { who meets clinical } \\
\text { criteria }\end{array}$ & $\begin{array}{l}\text { Easy bruising } \\
\text { Joint hypermobility, mostly } \\
\text { distal } \\
\text { Skin hyperextensibility and } \\
\text { fragility, wide or atrophic } \\
\text { scarring } \\
\text { Increased rate of infection } \\
\text { Hernias } \\
\text { Marfanoid facial features } \\
\text { Acrogeria } \\
\text { Prominent vasculature }\end{array}$ & $\begin{array}{l}\text { Severe, intractable } \\
\text { periodontitis of early } \\
\text { onset (childhood or } \\
\text { adolescence) OR lack } \\
\text { of attached gingiva } \\
\text { Plus at least } 2 \text { other } \\
\text { major criteria and one } \\
\text { minor criterion }\end{array}$ & $\begin{array}{l}\text { Identification of known or } \\
\text { compatible gain-of-function } \\
\text { mutations by sequence } \\
\text { analysis of } C 1 R \text { and } C 1 S\end{array}$ \\
\hline
\end{tabular}

* The Five-Point Questionnaire (5PQ):

1. Can you now (or could you ever) place your hands flat on the floor without bending your knees?

2. Can you now (or could you ever) bend your thumb to touch your forearm?

3. As a child, did you amuse your friends by contorting your body into strange shapes or could you do the splits?

4. As a child or teenager, did your shoulder or kneecap dislocate on more than one occasion?

5. Do you consider yourself "double-jointed"?

A "yes" answer to two or more questions (= positive 5PQ) suggests joint hypermobility with $80-85 \%$ sensitivity and 80-90\% specificity.

Adapted from Hakim AJ, Grahame R. A simple questionnaire to detect hypermobility: an adjunct to the assessment of patients with diffuse musculoskeletal pain. Int J Clin Pract 57:163-166, 2003.

\# In patients with an acquired connective tissue disorder (e.g. lupus, rheumatoid arthritis) additional diagnosis of hEDS requires meeting both features $\mathrm{A}$ and $\mathrm{B}$ of criterion 2 . Feature $\mathrm{C}$ of criterion 2 (chronic pain and/or instability) cannot be counted towards a diagnosis of hEDS in this situation. 


\section{REFERENCES}

1. Beighton P. The Ehlers-Danlos syndrome. London, England: William Heinemann Medical Books, 1970.

2. Beighton P, De Paepe A, Danks D, et al. International nosology of heritable disorders of connective tissue, Berlin 1986. Am J Med Genet 1988;29:581-594.

3. Beighton P, De Paepe A, Steinmann B, Tsipouras P, Wenstrup RJ. Ehlers-Danlos syndromes: revised nosology, Villefranche, 1997. Am J Med Genet 1998;77:31-37.

4. Malfait F, Francomano C, Byers P, et al. The 2017 International classification of the Ehlers-Danlos syndromes. Am J Med Genet Part C Semin Med Genet 2017;175C:8-26.

5. Steinmann B, Royce PM, Superi-Furga A. The Ehlers-Danlos syndrome. In: Royce Pm, Steinmann $\mathrm{B}$, eds. Connective tissue and its heritable disorders. $2^{\text {nd }}$ ed. New York, USA: Wiley-Liss, 2002:431-525.

6. Berk DR, Bentley DD, Bayliss SJ, Lind A, Urban Z. Cutis laxa: a review. J Am Acad Dermatol 2012;66:842.e1-17.

7. Firth H, Hurst J. Oxford Desk reference: Clinical Genetics. $1^{\text {st }}$ ed Oxford, England: Oxford University Press, 2005:138-139.

8. Rikken-Bultman DG, Wellink L, van Dongen PW. Hypermobility in two Dutch school populations. Eur J Obstet Gynecol Reprod Biol 1997;73:189-192.

9. Hakim AJ, Grahame R, Norris P, Hopper C. Local anaesthetic failure in joint hypermobility syndrome. J R Soc Med 2005;98:84-85.

10. Bowen JM, Sobey GJ, Burrows NP, et al. EhlersDanlos syndrome, classical type. Am J Med Genet Part C Semin Med Genet 2017;175C:27-39.

11. Colombi M, Dordoni C, Venturini M, et al. Spectrum of mucocutaneous, ocular and facial features and delineation of novel presentations in 62 classical Ehlers-Danlos syndrome patients. Clin Genet 2017;92:624-631.

12. Gaines R, Tinkle BT, Halandras PM, Al-Nouri O, Crisostomo P, Cho JS. Spontaneous Ruptured Dissection of the Right Common Iliac Artery in a Patient with Classic Ehlers-Danlos Syndrome Phenotype. Ann Vasc Surg 2015;29:595.e11-4.

13. Brady AF, Demirdas S, Fournel-Gigleux S, et al. The Ehlers-Danlos syndromes, rare types. Am J Med Genet Part C Semin Med Genet 2017;175C:70-115.

14. Demirdas S, Dulfer E, Robert L, et al. Recognizing the tenascin-X deficient type of Ehlers-Danlos syndrome: a cross-sectional study in 17 patients. Clin Genet 2017; 91:411-425.

15. Schwarze U, Hata R, McKusick VA, et al. Rare autosomal recessive cardiac valvular form of EhlersDanlos syndrome results from mutations in the COL1A2 gene that activate the nonsense-mediated RNA decay pathway. Am J Hum Genet 2004;74:917-930.

16. Byers PH, Belmont J, Black J, et al. Diagnosis, natural history, and management in vascular EhlersDanlos syndrome. Am J Med Genet Part C Semin Med Genet 2017;175C:40-47.
17. Frank M, Albuisson J, Ranque B, et al. The type of variants at the COL3A1 gene associates with the phenotype and severity of vascular Ehlers-Danlos syndrome. Eur J Hum Genet 2015;23:1657-64.

18. Legrand A, Devriese M, Dupuis-Girod S, et al. Frequency of de novo variants and parental mosaicism in vascular Ehlers-Danlos syndrome. Genet Med 2019;21:1568-1575.

19. Murray ML, Pepin M, Peterson S, Byers PH. Pregnancy-related deaths and complications in women with vascular Ehlers-Danlos syndrome. Genet Med 2014;16:874-880.

20. Loeys BL, Schwarze U, Holm T, et al. Aneurysm syndromes caused by mutations in the TGF- $\beta$ receptor. N Engl J Med 2006;355:788-798.

21. Pyeritz RE. Heritable thoracic aortic disorders. Curr Opin Cardiol 2014;29:97-102.

22. Tinkle B, Castori M, Berglund B, et al. Hypermobile Ehlers-Danlos syndrome (a.k.a. Ehlers-Danlos syndrome type III and Ehlers-Danlos syndrome hypermobility type): clinical description and natural history. Am J Med Genet Part C Semin Med Genet 2017;175C:48-69.

23. Syx D, Symoens S, Steyaert W, De Paepe A, Coucke PJ, Malfait F. Ehlers-Danlos syndrome, hypermobility type, is linked to chromosome 8p228 p21.1 in an extended Belgian family. Dis Markers 2015;2015:828970.

24. Grahame R, Bird HA, Child A. The revised (Brighton 1998) criteria for the diagnosis of benign joint hypermobility syndrome. J Rheumatol 2000;27:17771779.

25. Zweers MC, Bristow J, Steijlen PM, et al. Haploinsufficiency of TNXB is associated with hypermobility type of Ehlers-Danlos syndrome. Am J Hum Genet 2003;73:214-217.

26. Castori M, Morlino S, Grammatico P. Towards a rethinking of the clinical significance of generalized joint hypermobility, joint hypermobility syndrome, and Ehlers-Danlos syndrome, hypermobility type. Am J Med Genet A 2014;164A:588-590.

27. Castori M, Tinkle B, Levy H, Grahame R, Malfait F, Hakim A. A framework for the classification of joint hypermobility and related conditions. Am J Med Genet Part C Semin Med Genet 2017;175C:148-157.

28. Van Damme T, Colige A, Syx D, et al. Expanding the clinical and mutational spectrum of the Ehlers-Danlos syndrome, dermatosparaxis type. Genet Med 2016;18:882-91.

29. Giunta C, Baumann M, Fauth C, et al. A cohort of 17 patients with kyphoscoliotic Ehlers-Danlos syndrome caused by biallelic mutations in FKBP14: expansion of the clinical and mutational spectrum and description of the natural history. Genet Med 2018;20:42-54.

30. Burkitt Wright EM, Porter LF, Spencer HL, et al. Brittle cornea syndrome: recognition, molecular diagnosis and management. Orphanet $\mathbf{J}$ Rare Dis 2013;8:68. 
31. Okajima T, Fukumoto S, Furukawa K, Urano T, Furukawa K. Molecular basis for the progeroid variant of Ehlers-Danlos syndrome: identification and characterization of two mutations in galactosyltransferase I gene. J Biol Chem 1999;274:28841-28844.

32. Nakajima $\mathrm{M}$, Mizumoto $\mathrm{S}$, Miyake $\mathrm{N}$, et al. Mutations in B3GALT6, which encodes a glycosaminoglycan linker region enzyme, cause a spectrum of skeletal and connective tissue disorders. Am J Hum Genet 2013;92:927-934.

33. Giunta C, Elcioglu NH, Albrecht B, et al. Spondylocheiro dysplastic form of the Ehlers-Danlos syndrome - an autosomal recessive entity caused by mutations in the zinc transporter gene SLC39A13. Am J Hum Genet 2008;82:1290-1305.

34. Van Damme T, Pang X, Guillemyn B, et al. Biallelic B3GALT6 mutations cause spondylodysplastic Ehlers-Danlos syndrome. Hum Mol Genet 2018;27:3475-3487.

35. Janecke AR, Li B, Boehm M, et al. The phenotype of the musculocontractural type of Ehlers-Danlos syndrome due to CHST14 mutations. Am J Med Genet A 2016;170:103-15.

36. Uehara M, Kosho T, Yamamoto N, et al. Spinal manifestations in 12 patients with musculocontractural Ehlers-Danlos syndrome caused by CHST14/D4ST1 deficiency (mcEDSCHST14). Am J Med Genet A 2018;176:2331-2341.

37. Zou Y, Zwolanek D, Izu Y, et al. Recessive and dominant mutations in COL12A1 cause a novel EDS/myopathy overlap syndrome in humans and mice. Hum Mol Genet 2014;23:2339-2352.

38. Kapferer-Seebacher I, Pepin M, Werner R, et al. Periodontal Ehlers-Danlos syndrome is caused by mutations in $\mathrm{C} 1 \mathrm{R}$ and $\mathrm{C} 1 \mathrm{~S}$, which encode subcomponents $\mathrm{C} 1 \mathrm{r}$ and $\mathrm{C} 1 \mathrm{~s}$ of complement. Am J Hum Genet 2016;99:1005-1014.

39. Kapferer-Seebacher I, Waisfisz Q, Boesch S, et al. Periodontal Ehlers-Danlos syndrome is associated with leukoencephalopathy. Neurogenetics 2019;20:1-8.

40. Rinner A, Zschocke J, Schossig A, Gröbner R, Strobl $\mathrm{H}$, Kapferer-Seebacher I. High risk of peri-implant disease in periodontal Ehlers-Danlos Syndrome. A case series. Clin Oral Implants Res 2018 Sep 25. [Epub ahead of print]

41. Alazami AM, Al-Qattan SM, Faqeih E, et al. Expanding the clinical and genetic heterogeneity of hereditary disorders of connective tissue. Hum Genet 2016;135:525-40.

42. Blackburn PR, Xu Z, Tumelty KE, et al. Bi-allelic alterations in AEBP1 lead to defective collagen assembly and connective tissue structure resulting in a variant of Ehlers-Danlos syndrome. Am J Hum Genet 2018;102:696-705.

43. Hebebrand M, Vasileiou G, Krumbiegel M, et al. A biallelic truncating AEBP1 variant causes connective tissue disorder in two siblings. Am J Med Genet A 2019;179:50-56.
44. Syx D, De Wandele I, Symoens S, et al. Bi-allelic AEBP1 mutations in two patients with Ehlers-Danlos syndrome. Hum Mol Genet 2019;28:1853-1864.

45. Byers PH, Murray ML. Ehlers-Danlos syndrome: A showcase of conditions that lead to understanding matrix biology. Matrix Biol 2014;33:10-15.

46. Sulli A, Talarico R, Scirè CA, et al. Ehlers-Danlos syndromes: state of the art on clinical practice guidelines. RMD Open. 2018;4 (Suppl 1):e000790.

47. Ericson W, Wolman R. Orthopaedic management of the Ehlers-Danlos syndromes. Am J Med Genet Part C Semin Med Genet 2017;175C:188-194.

48. Engelbert RH, Juul-Kristensen B, Pacey V, et al. The evidence-based rationale for physical therapy treatment of children, adolescents, and adults diagnosed with joint hypermobility syndrome/hypermobile Ehlers-Danlos syndrome. Am J Med Genet Part C Semin Med Genet 2017;175C:158-167.

49. Chopra P, Tinkle B, Hamonet C, et al. Pain management in the Ehlers-Danlos syndromes. Am J Med Genet Part C Semin Med Genet 2017;175C:212219.

50. Mitakides J, Tinkle B. Oral and mandibular manifestations in the Ehlers-Danlos syndromes. Am J Med Genet Part C Semin Med Genet 2017;175C:220225.

51. Hakim A, de Wandele I, O’Callaghan C, Pocinki A, Rowe P. Chronic fatigue in Ehlers-Danlos syndrome, hypermobile type. Am J Med Genet Part C Semin Med Genet 2017;175C:175-180.

52. Hakim A, O'Callaghan C, de Wandele I, Stiles L, Pocinki A, Rowe P. Cardiovascular autonomic dysfunction in Ehlers-Danlos syndrome, hypermobile type. Am J Med Genet Part C Semin Med Genet 2017;175C:168-174.

53. Fikree A, Chelimsky G, Collins H, Kovacic K, Aziz Q. Gastrointestinal involvement in the Ehlers-Danlos syndromes. Am J Med Genet Part C Semin Med Genet 2017;175C:181-187.

54. Bulbena A, Baeza-Velasco C, Bulbena-Cabré A, et al. Psychiatric and psychological aspects in the EhlersDanlos syndromes. Am J Med Genet Part C Semin Med Genet 2017;175C:237-245.

55. Voermans NC, van Alfen N, Pillen $\mathrm{S}$ et al. Neuromuscular involvement in various types of Ehlers-Danlos syndrome. Ann Neurol 2009;65:687697.

56. Henderson FC, Austin C, Benzel E, et al. Neurological and spinal manifestations of the Ehlers-Danlos syndromes. Am J Med Genet Part C Semin Med Genet 2017;175C:195-211 